\title{
Mondor' Disease in a Patient with Hepatitis C: A Case Report
}

\author{
Rosa Giménez-Garcia * \\ Clinical Assistant. Hospital Rio Hortega. Valladolid. Spain \\ Associate Professor. Department of Medicine, Dermatology and Toxicology. Faculty of Medicine. \\ Valladolid. Spain.
}

\section{INTRODUCTION}

Mondor'disease was originally reported by Henry Mondor in 1939 as unilateral thrombosis of the superficial veins of the antero-lateral thoracic wall.[1-5]Penile Mondor's disease is a thrombosis of the dorsal superficial veins of the penis [6] The aetiology is unknown. It is rarely associated with viral infections [7,8] and to our knowledge the case in this report is the second case of MD in a patient with hepatitis $\mathrm{C}$.

\section{CASE REPort}

A 47-year-old woman presented to us with palpable and painful cord-like in duration on her left breast. Few days later she developed a similar lesion affecting her left thoracoepigastric vein (Fig 1). She was smoker and has a family history ok stroke but there was no history of trauma or malignancies. Bilateral mammographic examination was normal. Ultrasonographic examination showed a hypoechoic tubular structure (Fig 2) Laboratory investigations including a thrombophilia study and anticardiolipin antibodies were within normal range. Liver test revealed a light elevation of transaminases levels. Hepatitis $\mathrm{C}$ antibodies were positive. The patient was diagnosed as having Mondor's disease on the basis of these findings and after 5 months of treatment with pentoxiphilline 600 twice, lesions have partially regressed.

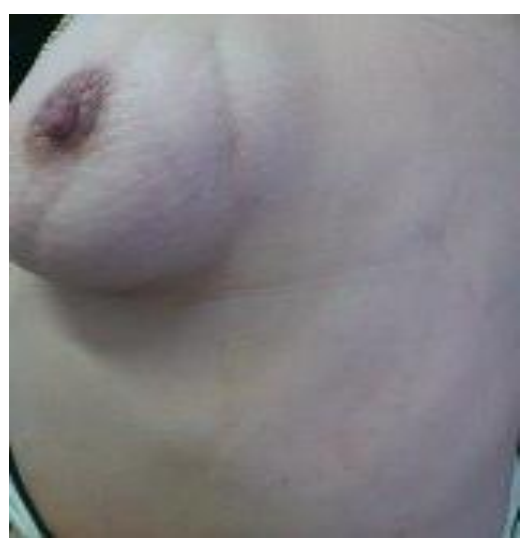

Fig1. palpable and painful cord-like in duration on her left breast

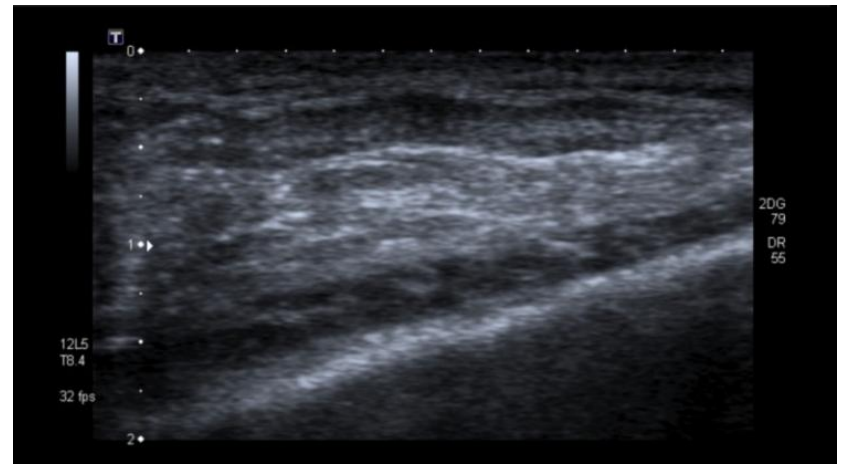

Fig2. A tubular hypoechoic lesion is seen in the subcutaneous layer 


\section{DISCUSSION}

Mondor's disease (MD) is a rare form of superficial thrombophlebitis commonly affecting the thoracoepigastric, lateral thoracic or superior epigastric veins. The pathogenesis of the disease is unclear but related with vessel-wall damage, stasis and hypercoagulable state .Histopathological findings include obstructed or obliterated vasculitis [1,5]

Clinically is characterized by subcutaneous tender, usually unilateral cord-like phlebitis commonly on the breast or anterior chest wall but it can also involve the penis, groin, antecubital fosse, and posterior cervical region. Most of the cases are idiopathic but trauma, surgery, excessive physical activity and rarely breast carcinoma have been considered a predisposing factor. It is rarely associated with hereditary protein $\mathrm{C}$, protein S deficiency or infections as herpes zoster and hepatitis C. [1,7-12] A higher prevalence of hepatitis $\mathrm{C}$ virus in patients with thrombosis and association with antiphospholipid antibodies has been demonstrated [10,11].MD has been described after a mammotome biopsy and after transaxillary breast augmentation $[12,13]$. Doppler ultrasound is the technique of choice for confirming the diagnosis [14].

Treatment is based on nonsteroidal anti-inflammatory medication. The use of anticoagulation is controversial but may prove useful in patients with coagulation disorders.[1-5, 11]

\section{REFERENCES}

[1] Alvarez-Garrido H. Garrido-Rios A.A. Sanz-Muñoz C. Miranda-Romero A. Mondor's disease. Clin Exp Dermatol 2009,34,753-756.

[2] Dirschka T. Winter K. Bierhoff E. Mondor's disease: A rare cause of anterior chest pain. J Am Acad Dermatol 2003; 49:905-6.

[3] Kondo T. Traumatic funicular phlebitis of the thoracic wall resembling Mondor's disease: a case report. J Med Case Reports 2011, 5:127-8.

[4] Onder M. Canpolat B. Aksakal B. Ali Gurer M. Case of Mondor's disease of the abdomen (body-building induced). Int J Dermatol 2005; 44:345-6.

[5] Ichinose A. Fukunaga A. Terashi H. Nishigori C.Tanemura A. Nakajima T. Akishima-Fukosawa Y. Objetive recognition of vascular lesions in Mondor's disease by immunohistochemistry. J Eur Acad Dermatol Venereol 2008, 22,168-173.

[6] Öztürk H. Penile Mondor's disease . Basis Clin Androl 2014;3:24:5

[7] Holle-Robatsch S. Fink AM. Schubert C. Steiner A. Partsch H. Mondor phlebitis associated with hepatitis C. Vasa 2001, 30:297-8.

[8] Yang JH. Lee UH. Jang SJ. Choi JC. Mondor's disease probably due to herpes zoster. Eur Acad Dermatol Venereol 2005; 19:774-5.

[9] Rodriguez-Peralto JL. Carrillo R. Rosales B. Rodriguez-Gil Y. Superficial Thrombophlebitis. Semen Cutan Med Surg 2007; 26, 26: 71-6

[10] Violi F. Basili S. Artini M. Valesini G. Levrero M. Cordova C. Increased rate of thrombin generation in hepatitis $\mathrm{C}$ virus cirrhotic patients. Relationship to venous thrombosis. J investing Med 1995;43:550-4

[11] Kisiel E. Kryckka W. Antiphospholipid antibodies with HCV infection. Innocent proteins or risk factor?. Przegl Lek 2007:64: 521-4

[12] Pereira de Godoy JM, Fernandes Godoy M, Batigália F, Marcolino Braile D. The association of Mondor's disease with protein S deficiency: case report and review of literature J Thrombosis and thrombolysis 2002; 13:187-189

[13] Kibil W, Hodorowicz-Zaniewska D, Kulig J. Mondor's disease in a patient after mammotome biopsy. Wideochir Inne Tech Maloinwazyjne 2015; 10:138-140

[14] Niechajev I. Mondor's subcutaneous banding after transaxillary breast augmentation: case report and the review of literature. Aesthetic Plast Surg 2013; 37: 767-9

[15] Jiunn-Chang L. Chien-Liang L. Tsang-Pai L. Kuo-Shyang J. Tsen-Long Y. The sonographic findings of Mondor's disease in the breast. J Med Ultrasound 2002; 4:202-4. 